\title{
The Level of Self-concept, School Culture and School Climateamong Students in Selangor
}

Sabarnur Abd Radzak, Amna Md Noor, Azlina MohdKhir

To Link this Article: http://dx.doi.org/10.6007/IJARBSS/v11-i11/11369

DOI:10.6007/IJARBSS/v11-i11/11369

Received: 06 September 2021, Revised: 11 October 2021, Accepted: 27 October 2021

Published Online: 16 November 2021

In-Text Citation: (Radzak et al., 2021)

To Cite this Article: Radzak, S. A., Noor, A. M., \& MohdKhir, A. (2021). The Level of Self-concept, School Culture and School Climateamong Students in Selangor. International Journal of Academic Research in Business and Social Sciences, 11(11), 1198-1212.

\section{Copyright: @ 2021 The Author(s)}

Published by Human Resource Management Academic Research Society (www.hrmars.com)

This article is published under the Creative Commons Attribution (CC BY 4.0) license. Anyone may reproduce, distribute, translate and create derivative works of this article (for both commercial and non-commercial purposes), subject to full attribution to the original publication and authors. The full terms of this license may be seen at: http://creativecommons.org/licences/by/4.0/legalcode

Vol. 11, No. 11, 2021, Pg. 1198 - 1212

Full Terms \& Conditions of access and use can be found at http://hrmars.com/index.php/pages/detail/publication-ethics 


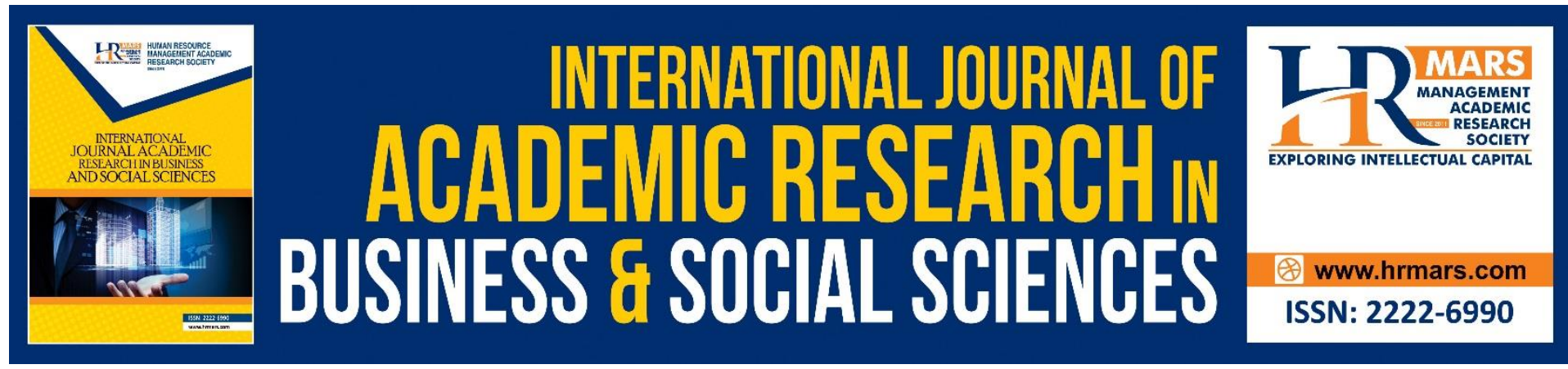

\title{
The Level of Self-concept, School Culture and School Climateamong Students in Selangor
}

\author{
Sabarnur Abd Radzak, Amna Md Noor, Azlina MohdKhir
}

Department of Social and Development Sciences, Faculty of Human Ecology, Universiti Putra Malaysia, 43400 Serdang, Selangor, Malaysia

Email: zur_ain17@yahoo.com

\begin{abstract}
The aim of the present study is to determine the level of self-concept, school culture and school climate among students in Selangor. This study involved 400 adolescents aged 14and 16 years old from eight secondary schools in the state of Selangor. Respondents were selected through multi-stage cluster sampling.Data were collected using questionnaires through a selfadministered procedure which are consists of social demographic background, school climate and school culture (Inventory of Parents and Peer Attachment (IPPA), Questions of Teacher's Interaction (QTI),School Self-Review Tools (SSRT), Multidimensional Scale of Perceived Social SupportZimet) and self-concept (Self Concept-Individual Protective Factors Index). Overall, the level of self-concept, school culture and school climate are moderate among students in Selangor. The awareness of the influence and impact of self-concept, school culture and school climate involved in the adolescent development system is imperative. As a conclusion, adolescents' involvement in various self-development programs preventing them from engaging in delinquency activitiesthus safeguardingstudents'psychosocial well-being. Suggested recommendations were discussed for future research of the present study.
\end{abstract}

Keywords: Adolescence, School Culture, School Climate, Self-Concept, Behaviour

\section{Introduction}

Currently, the population of adolescents between the ages of 10 to 19 is nearly 1.2 billion.In addition, there are 344 million adolescent populations in South Asia meanwhile 296 million in East Asia and Asia Pacific (UNICEF, 2018).In several countries, youth populationis a quarter of the population and this number is expected to increase by 2050 especially in low -income countries.There are numerous policies implemented to focusing and maintaining the well being of adolescentsworldwidely. The United Nations Strategy in 2018 has concentrate the quality in education and health services among adolescent through the Agenda for Sustainable Development of 2030. Theobjective of the global strategy that introduced in 2016 till 2030 by United Nation for Women, Children and Adolescents Health is to improving health and well-being, as well as recognizing adolescents as key success of the Agenda for Sustainable Development 2030.The diverse needs of adolescents have been identified and recognized such as health, economic growth, employment opportunities, gender equality, education, nutrition and poverty reduction. 
Adolescence derived from the Latin term and the meaning is growing up towards maturity. Adolescence is a stage towards the formation of attitudes and beliefs that necessary for an effective involvement in society. The adolescent stage is also a phase for physical growth, a stage in growth, a stopping point and a sociocultural phenomenon (Rogers, 1981).Adolescence is an importantstage in human development with challenging physical, psychosocial, cognitive, emotional, and sexual activity development.Though biological elements affect the adolescent health and self-development, social contexts including family, media, school, and neighborhood similarly have significant implications for their well -being (WHO, 2017).

Social problems consist a variety of negative behaviors in members of society that do notoffered benefitto the strength of the structure and economic system that practiced by a society, community or nation (Sharif \& Roslan, 2011). These negative behaviors are divided by two categories namely external behaviors and internal behaviors.According to Achenbach \& Edelbrock (1983), externalising behavior is impulsiveand lacks of self-control such as aggressive and repeatedly harassing others. These individuals are always prone to behavioral problems that affect learning and social relationships. While internalizing behavior is refer to the isolating themselves, compulsive, sad mood, shy, fear and fantasy. These situations may not be perceived by the teacher because it is not disruptive but this behavior affects learning and normal social relationships.

Nowadays, there are many factors that drive teenagers to engage in unhealthy social problems such as socio-demographic background of the adolescents including age, gender, education level and household income.Referring to the phenomena of substance abuse, age is asingle element that influencing alcohol consumption among adolescents that aged 14 to 19 years (Madruga et al, 2012).According to the study conducted by Zulkifli \& Low (2000) on the issue of sexual intercourse among unmarried adolescents in Malaysia, $18.18 \%$ of them are males and $7.11 \%$ were females.In addition, various factors such as peer influence (Ludden \&Eccels, 2007), social support (Tam \& Lim, 2009) and environmental factors (Chandra et al., 2008) also influence the existence of social problems among adolescents. When discussing on environmental factors that contribute to the social problems among adolescents, the concept of school culture and climate should be understood critically.

\section{School Culture and School Climate}

The concept of school culture refers to the method of teachers and school staff by sharing a similiarset of beliefs, values, and assumptions torespresentschool identity and determining standards for shaping student behavior (Muhammadi et al., 2015).During 21st century, the concept of school culture isdynamic and parallel with the recent progress. The Ministry of Education Malaysia through the Malaysian Education Development Plan (PPPM) 2013-2025 emphasize the culture of excellence based on peer leadership should be implemented in schools. The statement clearly highlights that school culture is a significant element and needs to be shaped systematically to preventing deficiency ahead (Kaplan, et al., 2013).In addition, school culture has a strong impact and serves to educate the community in the school setting as well as social reaction. Banks (1993); Deal \& Peterson (1998) stated that school culture refers to the social system that encompasses its own culture across institutional norms, social structures, goals and objectives.If the school culture is in respectable condition, then the quality of discipline is reputable.Generally, when a students have disciplinary problems directly,they will less interest to learning and planning their own future. The issue of the moral 
deterioration and student discipline is a very well-known current issues and creating a negative perception to the education system.

Undoubtedly school climate also plays a significant role in line with the concept of school culture.The Center for Curriculum Development in 1981 defined school climate as a respectable school atmosphere where the environment is comfortable, peaceful, friendly, cheerful with smooth learning.According to Brookover, et.al. (1979), an appropriate school climate can further improvethe academic achievement and external and internal behavior of students.Obviously,students couldn't concentrateon their study peacefully if the school environment is chaotic, dirty, smelly and noisy. Not only that, a bad relationship between students and teachers who are not friendly, as well students who are naughty and quarrelsome.This situation contributes to the worsening of student performance, truancy problems and student discipline that are difficult to curb as a result of the negative school climate and environment.In general, school climate and environment play an important role in the formation of behavior, mental image, aspirations and social interactions. In addition, a positive school climate should emphasize a respectable relationshipand strong cooperation between administrators, teachers, students, parents, and the community (Rudasill et al., 2018). As a result, family atmosphere transpires among the school staffthat indirectly improve students' academic achievement.

School culture and school climate play a vital element in determining the school achievement.Both of these concepts are important in improving students internal and external performanceand behavior. On the past decade, Western researchers noticed that the reformation of school climate probably worthless if they are no strong correlation with school culture (Peterson, 1999). Although several studies clarified the concept of school culture and school climate are different concepts but these two concepts are related to each other andprovides similar characteristics (Wahab et al., 2018).In this study, school culture and school climate refer to the relationship between students, the relationship between teachers and students, school environment factors, social support in school and the counseling system in school.

A positive school culture and school climate encompasses a strong school spirit and positive self -concept among adolescents (Wahab et al., 2018). During the developmental stage of adolescence, they will experience several changes physically and mentally.These characteristics plays an important aspect in the formation of teenager's self-concept. The concept of self is a combination of self-assessment, the assessment of others and assessment of other people's perceptions of himself.According to Wahab et al (2018) self -concept is a person's perception of himself that incorporates beliefs, feelings, attitudes and values.Self conceptis a significantly important because it is the personal identity of a person that is seen by himself that would bring maturity to adolescence and evaluates their behavior to meet his ideal desires. Fraken (1994) in his study specified self -concept refers to motivated behavior and a backbone to one's behavior. Thus, with a respectable relationships and social support received from teachers as well as peers in the school, it can improve adolescent self -concept in forming positive internal and external behaviors.

In Malaysia, the existing learning system led toeach individual spending one-third of their age in school, starting with pre-school education, primary education, secondary education, post secondary education and higher education (Franken, 1994).According to the schooling period,clearly proven that the school system and the processes are important as the family and community systems to formulate internal and external behavior of adolescents.Besides family system, the environment and the school system are the closest to adolescents.Allen- 
Meares (2007) clarified that the school environment plays a key role in adolescent social development.Empowering schools as locations to deliver the education process and provide social services thatenhancing self-development is an effective approach in constructing responsibleindividuals and addressing adolescents' social problems (Amna et al., 2003).This statement is also supported by Allen-Meares (2007) because it is an effective way in detecting and addressing social problems among adolescents by emphasizing school culture and school climate.There isa study that revealed the high-achieving schools accomplish the reputable level of cheerfulness compared to the schools with low levels of cheerfulness (MohdRedzauddin bin Ismail, 2008).Indeed, the school culture and school climate relativelyimportant to helping studentslearn peacefully and comfortably as well assists students to formulate their self -concept, internal and external behaviors in a positive way.

\section{Self-concept, School Culture and School Climate}

Self-concept is a very important dimension in a human development. Combs (1981) specified in his study that the self-concept related to the personal experience of an individual. The acknowledgement of the self-concept as a dynamic process in human behavior is an appreciation in the field of human psychology (Combs, 1981). Directly, this dynamic process proves that the concept of self-concept is an important aspect in studying human development. Through various changes and modernization today, an individual is supposed to have a high self -concept.

Self-concept is considered as a significant agent influencing social functioning and behavior of adolescent resulting in a variety of mental health related problems (Marsh, Parada, \& Ayotte, 2004).In addition, self-concept is a respectable element for promoting individual wellbeing as well as preventing psychological problems (Gilman \& Huebner, 2006; Orth, Robins et al., 2009; Orth et al., 2012).

Adolescents may limit the socialization process if they have a low self-concept meanwhile adolescents with high self-concept are likely to experienced more social interactions.Previous research has also described that high self-concept as an excessive positive vision of the self (Gresham et al., 2000). For example, the low levels of self-esteem are associated with criminal activity and social harassment (Trzesniewski et al., 2006).According to the labelling theory, when problematic labels are expressed to the individual consequently would producing a weak self-conceptthat affecting social position (Bernberg \& Krohn, 2003; Bernberg et al., 2006; Levy, 1997).

The role of teachers is identical important in the developing a positive or negative selfconcept among students (Eggen, 2004). A positive school climate also encompasses strong school spirit to developing a positive self-concept among students and staff (Rudasill et al., 2017). Self-concept is considered as an important psychological construction in human beings and influencing other variables. Recognizing the importance of self-concept in the education, Lillemyr et al (2004) mentioned that Western school institutions is essential to forwardly looking the aspect of self-concept in learning process as a major source of student motivation. Seaton et al (2004) explained that the positiveself-concept in academicis a primary goal in educational field.This statement was supported by the study of Ming \&Kong (2003) and they found a student that have a low self-concept are not motivated and experienced a learning difficulty.Thus, Johansson (2004) suggested that self-concept should be emphasized in the student development programme because it has a relationship with education and human life. Furthermore, self-concept also influencing deviant behavior amongstudents. This 
statement is proven when the adolescents with a high self-concept are less involved in a deviant behaviourmeanwhile the adolescent with a low self-concept are actively involved in deviant behaviour. This statement is well supported by Asiah (2001) who stated that problematic student experienced a negative self-concept meanwhile for non-problematic students experienced a positive self-concept. Lin (2009) specified that students with a low self-concept didn't like to attending school because the loneliness and marginalized by schoolmates.

Besides arole of the teacher, the self-concept also developed by peer pressure or relationship between student.The definition of self-concept is viewed contrarily depending on the importance of peers among adolescents (Bokhorst, Sumter, \&Westenberg, 2010).Previous studies identified the adolescents with conflicting self-concepts have been associated with internal and external behavioral problems.Adolescents acknowledge that the quality of time that their spent with peers is worthwhile and easily influenced by the peer'sbehaviour. In addition, earlier studies have identified that interaction with peers influencing the development of self -concept (Rill et al., 2009; Mota \& Matos, 2013; Thomaes et al., 2010).Individual self-esteemand self-concept could be stable due to the high acceptance by peers, meanwhilehigh rejection by peers lowering the self-esteem and self-concept respectively (Matsunaga, 2011).The level of acceptance among peer groups is essential for the stability of self-concept thus previous studies strongly agree that self-concept related to engagement with peers positively or negatively.

Recently, adolescents are exposed to the social phases andextreme deviations in social roles and peers'relationships. Quality friendships are closely associated with high levels of selfesteem meanwhile poor relationships are associated with delinquent behavior among adolescents (Obiunu, 2015).Ngai \&Cheung (2005) mentioned peer rejection is related to the low self-concept. However, there are limited local studies in relating cultural concepts, school climate, self -concept among adolescents in Malaysia. Therefore, this study aims to examine the level of school culture and school climate, self-concept among adolescents especially in Selangor schools.

\section{Methodology}

\section{Population, sample and location of study}

The study was conducted in the state of Selangor where the state has the highest number of secondary schools in Malaysia which is 278 schools. The schools involved are SMK Taman Medan (Petaling Utama), SMK Dato' Harun (Petaling Utama), SMK Bandar Baru Salak Tinggi (Sepang), SMK Seri Sepang (Sepang), SMK Jalan Tiga (Hulu Langat), SMK Bandar Baru Bangi (Hulu langat), SMK Munshi Abdullah (Sabak Bernam), dan SMK Bagan Terap (Sabak Bernam).Students that aged between 14 and 16 years are the population in this studybecause the Ministry of Education has emphasizes only students who are not involved in public examinations are allowed to partcipate in this research.According to Krejcie\&Morgan (1970), the sample size for a population larger than 27,010 was 379 students. Finally, the sample of the study is 400 students $(\mathrm{N}=400)$ and respondents were selected through multistage cluster sampling technique. 
Table 1: The Distribution Number of Respondents by Location ( $N=400)$

\begin{tabular}{ll}
\hline List of School & $\mathbf{n = 4 0 0 ( \% )}$ \\
\hline SMK Taman Medan (Petaling Utama) & $37(9.25)$ \\
SMK Dato' Harun (Petaling Utama) & $47(188)$ \\
SMK Bandar Baru Salak Tinggi (Sepang) & $68(17)$ \\
SMK Seri Sepang (Sepang) & $65(16.25)$ \\
SMK Jalan Tiga (Hulu Langat) & $66(16.5)$ \\
SMK Bandar Baru Bangi (Hulu langat) & $66(16.5)$ \\
SMK Munshi Abdullah (Sabak Bernam) & $26(6.5)$ \\
SMK Bagan Terap (Sabak Bernam) & $25(6.25)$ \\
\hline
\end{tabular}

\section{Instruments}

For the present study, thequestionnaire is divided into 3 dimensions namelySection $A$ : Background of respondents and family, Section B: School Culture and School Climate, and Section C: Self-Concept. The demographic background of the respondents consists of two subtopics specifically student and family background. The Culture and School Climate Scale is divided into 5 subscalesspecifically the relationship between students through (Inventory of Parents and Peer Attachment (IPPA), relationships between teachers and students (Questions of Teacher's Interaction (QTI),school environment (School Self-Review Tools) (SSRT), social support and counseling support (Multidimensional Scale of Perceived Social Support). In conclusion, there are 80 questions in this school culture and school climate. This self-concept scale is seen based on the score obtained by the respondents based on 16 items adapted from the Self-concept-Individual Protective Factors Index.

\section{Analysis of Data}

Data were analysed by descriptive statistics based on frequency, mean, standard deviation, minimum and maximum to determine the level of self-concept, school culture and school climate among students in Selangor. 


\section{Results and Discussions}

a) Socio-demographic Profile

Table 2: Socio-demographic Profile of Respondents( $N=400)$

\begin{tabular}{lll}
\hline Profile & $\mathbf{n}$ & $\%$ \\
\hline Age & & \\
14 & 239 & 59.8 \\
16 & 161 & 40.3 \\
& & \\
Mean:1.45; SD:0.498, & & \\
Minimum:14, Maximum:16 & & \\
Gender & & \\
Male & & \\
Female & 183 & 45.8 \\
& 217 & 54.3 \\
Number of siblings & & \\
1 & & \\
$2-3$ & 9 & 2.3 \\
$4-5$ & 143 & 35.8 \\
$6-7$ & 176 & 44.0 \\
$>7$ & 54 & 13.5 \\
Mean:4.21; SD:1.76 & 18 & 4.5 \\
Minimum:1; Maximum:12 & & \\
\hline
\end{tabular}

Table 2 presents the distribution of frequencies and percentages of respondents based on their age, gender and number of siblings. This study involved a total of 400 school students in the state of Selangor. The respondents of this study are adolescents that aged 14 years and 16 years who were form two and four students. Most of the respondents are 14 years old with 239 (59.8\%) compared 16 years old with 161 (40.3\%). For the gender distribution, most of the respondents are female with 217 (54.3\%) meanwhile 183 are male 183 (45.8\%). In addition, majority of respondents are married (80\%) with less than five number of households (75.5\%). The percentage of form two students was seen to be higher than the percentage of form four students due to the possibility of transfering to boarding school after completing the lower secondary assessment or changing to another school due to certain factors such as families'affairs and others. The majority of respondents had a number of siblings between four to five people (44.0\%). The minimum number of siblings is one $(2.3 \%)$ which is the lowest score. Meanwhile the maximum number of siblings is twelve people, which is more than seven siblings (4.5\%). According to Noraziah's (2003) the number of siblings influencing delinquent behavior among adolescent. However, a study by Mohd. Kosnin, Azlina\& Mustapha, Suzila (2010) are initiate that there is no significant relationship between the number of siblings with delinquent behavioramong students.

\section{b) The level ofschool culture and school climate, and self-concept}

The results in Table 3 shows the distribution of school culture and school climate that include five main domains namely relationship between student $(M=79.64 S . D .=12.25)$, relationship between student and teacher $(M=83.72$, S.D.=14.29), school environment $(M=62.85$, 
S.D.=10.19), social support $(M=44.53, S . D .=7.53)$ and counselling support $(M=41.40$, S.D.=6.46).The results of the study initiate that relationship between student andteacher led the highest mean score followed by the domain of relationship betweenstudent, school environment, social support and counselling support. The results of this study prove that the role of teachers is very important in the development of positive or negative self-concept among students Eggen (2004). Teachers also as a parent in school therefore, a good relation between teachers and students are highly encouraged to curb unhealthy symptoms among students.

Table 3 Distribution of school culture and school climate ( $N=400)$

\begin{tabular}{|c|c|c|c|c|c|c|}
\hline Item & $\begin{array}{l}\text { No. of } \\
\text { item }\end{array}$ & Score & Mean & SD & Minimum & Maximum \\
\hline $\begin{array}{l}\text { Relationship } \\
\text { between } \\
\text { Student }\end{array}$ & 23 & 5 & 79.64 & 12.25 & 29.00 & 107.00 \\
\hline $\begin{array}{l}\text { Relationship } \\
\text { between } \\
\text { teacher and } \\
\text { student }\end{array}$ & 20 & 6 & 83.72 & 14.29 & 37.00 & 118.00 \\
\hline $\begin{array}{l}\text { School } \\
\text { environment }\end{array}$ & 18 & 5 & 62.85 & 10.19 & 32.00 & 87.00 \\
\hline $\begin{array}{l}\text { Social } \\
\text { Support }\end{array}$ & 8 & 7 & 44.53 & 7.57 & 15.00 & 60.00 \\
\hline $\begin{array}{l}\text { Counselling } \\
\text { Support }\end{array}$ & 11 & 5 & 41.40 & 6.46 & 18.00 & 55.00 \\
\hline
\end{tabular}

\section{The Level of School Culture and School Climate}

From the results in table 4, the level of relationship between student showed that the respondents reached a moderate level followed by a high level $(M=79.64$, S.D. $=12.25)$. This situation is paralleh with the study by Zainudin \& Norazmah (2011) where the findings exposed that the self factors most influencing reason of respondents involved in social problems compared to the peers influence and school environment problems. From the results in table 3, the level of relationship between teacher and student showed that the respondents reached a moderate level followed by a high level $(M=83.72$, S.D. $=14.29) .70 .8 \%$ of respondents have a moderate level of relationship and following by $15.3 \%$ are at a high level. Meanwhile only $13.8 \%$ of respondents have a low level of relationship. Therefore, schools' teachers need to explore an effective method to approach the students. According to Shochet et al (2006) a good school climate is highly related to the elements of relationships and close attachment with students. Furthermore, according to Stolp (1995) leadership among teacher influencing students to shape the appropriate culture to ensuring trusworthy to them compared parents.

From the results in table 4 , the level of school environment showed that the respondents reached a moderate level followed by a high level $(M=62.85$, S.D. $=10.19)$. More than onehalf or $67.8 \%$ of the respondents answered that the school environment was at a moderate level. Mean while, $18.3 \%$ at high levels following by $14 \%$ at low levels. This result illustrates the school probably further improve the school environment to inculcate a sense of interest among students to attending school. Students who felt less appreciated by the school 
environment will typically experience higher levels of anxiety and depression (Shochet et al., 2006). From the results in table 3, the level of social support showed that the respondents reached a moderate level followed by a high level $(M=44.53 \%$, S.D. $=7.57)$. The moderate level was at the highest score (73.8\%) compared to the other domains. Meanwhile, $(12.3 \%)$ were at a high level following by $14 \%$ of respondents felt that social support in school was at a low level. Students who experienced low level of autonomy and lack of social support in school demonstrates a greater absenteeism as well as symptoms of extreme depression (Virtanen et al., 2009).

Table 4: The level of school culture and school climate $(\mathrm{N}=400)$

\begin{tabular}{|c|c|c|c|c|c|c|c|}
\hline Item & $\begin{array}{l}\text { No } \\
\text { of } \\
\text { Item }\end{array}$ & n & $\%$ & Mean & SD & Minimum & Maximum \\
\hline $\begin{array}{l}\text { Relationship between } \\
\text { Student }\end{array}$ & 23 & & & 79.64 & 12.25 & 29.00 & 107.00 \\
\hline Low (29-67) & & 55 & 13.8 & & & & \\
\hline Moderate (68-91) & & 276 & 69.0 & & & & \\
\hline High (92.107) & & 66 & 16.5 & & & & \\
\hline $\begin{array}{l}\text { Relationship between } \\
\text { teacher and student }\end{array}$ & 20 & & & 87.32 & 14.29 & 37.00 & 118.00 \\
\hline Low (37-69) & & 55 & 13.8 & & & & \\
\hline Moderate (70-97) & & 283 & 70.8 & & & & \\
\hline High (98-118) & & 61 & 15.3 & & & & \\
\hline School environment & 18 & & & 62.85 & 10.19 & 32.00 & 87.00 \\
\hline Low (32-52) & & 56 & 14.0 & & & & \\
\hline Moderate (53-72) & & 271 & 67.8 & & & & \\
\hline High (73-87) & & 73 & 18.3 & & & & \\
\hline Social Support & 8 & & & 44.53 & 7.57 & 15.00 & 60.00 \\
\hline Low (15-36) & & 56 & 14.0 & & & & \\
\hline Moderate (37-52) & & 295 & 73.8 & & & & \\
\hline High (53-60) & & 49 & 12.3 & & & & \\
\hline Counselling Support & 11 & & & 41.40 & 6.46 & 18.00 & 55.00 \\
\hline Low (18-34) & & 58 & 14.5 & & & & \\
\hline Moderate (35-46) & & 258 & 64.5 & & & & \\
\hline High (47-55) & & 84 & 21.0 & & & & \\
\hline
\end{tabular}

\section{The Level of self-concept}

The results of the study initiate that the average score for all items in the self-concept was between an average of 29-53. The highest item in this variable was "I was a person with manners" ( $M=3.11$, S.D. = 0.647). The second highest item was "I can get along well with others" (M=3.03, S.D. = 0.634). Meanwhile the lowest item $(M=2.32$, S.D. $=0.806)$ which is "difficult for me to get friends". Overall, the analysis in the table 5 below showed that the majority of respondents (87.5\%) had a moderate level of self -concept. Meanwhile only $11.5 \%$ show at a high level of self-concept and only $1.0 \%$ have a low level of self -concept. Asiah's (2001) in her findings revealed that problematic students having a negative self-concept, whereas non-problematic students have a positive self-concept. In addition, Heng Ai Lin (2009) stated that students with low self -concept do not like to come to the school. Thus, in 
preventing unexpected problems ahead, self-concept among students should be heightened with the cooperation of the school staff, community and parents.

Table 5: The level of self -concept

\begin{tabular}{llllllll}
\hline Item & $\begin{array}{l}\text { No. of } \\
\text { item }\end{array}$ & $\mathbf{n}$ & $\%$ & Mean & SD & Minimum & Maximum \\
\hline $\begin{array}{l}\text { Self-Concept } \\
\text { Low (29-38) }\end{array}$ & 16 & & & 43.20 & 3.60 & 29.00 & 53.00 \\
$\begin{array}{l}\text { Moderate (39- } \\
\text { 46) }\end{array}$ & 350 & 87.5 & & & & \\
High (47-53) & & 46 & 11.5 & & & & \\
\hline
\end{tabular}

\section{Conclusion}

The present study revealed an overview of the level of school culture and school climate, selfconcept, among students in Selangor. The study involved 400 adolescents from SMK Taman Medan (Petaling Utama), SMK Dato' Harun (Petaling Utama), SMK Bandar Baru Salak Tinggi (Sepang), SMK Seri Sepang (Sepang), SMK Jalan Tiga (Hulu Langat), SMK Bandar Baru Bangi (Hulu langat), SMK Munshi Abdullah (Sabak Bernam), dan SMK Bagan Terap (Sabak Bernam). The findings of the present study also found that the level of self-concept, school culture and school climate is moderate among students in Selangor. major findings of this study. This is a good sign show that the student in Selangor still encountered that the self-concept, school climate and school culture are crucial element in the mainstream of the human development process. In addition, the moderate level of self-concept, school culture and school climate influenced the students as the client, perceived the changes in quality of education offered. In this study, researchers confidently claimed that the teachers play an important role to shaping a moderate level of self-concept, school climate and school culture among student. However, we can't be quick to be satisfied with a moderate level and there is much opportunity to ensure the level of self-concept, school climate and school culture are highly noticed ahead. The highly level of self-concept, school climate and school culture among students need to emphasize from today. From the view of researchers, the self-concept among students should be delicate continuously because it wil give an honourable impact to the development of school climate and school culture ahead.

However, future research recommendation needs to formulating the school or parental control model on delinquency behavior for effective monitoring strategies among adolescent in Malaysia. This alternative is to ensuring the impact of the future study to the development of adolescent behaviour. The sample of this study is limited to the adolescent in secondary school that aged of 14 and 16 years old in the State of Selangor only and these findings couldn'tgeneralize outside from this population.Therefore, future studies should include more adolescent in Malaysia besides 14 and 16 years old. In fact, the future research recommendation should conduct longitudinal studies to explain the patterns and long-term effects of respondent's involvement incapacitating delinquency behavioral problems from young age to the adulthood.

The findings of the present study require social psychologists to demonstrate a holistical understanding of how self-concept can be influenced by school culture and school climate. Thus, this situation may encourage social psychologists to conduct further studies that emphasize self-concept as a protective factor against extreme delinquency behavioral problems among adolescents. The self-development programs among adolescent would 
resulting them to not engaging delinquency behaviors. Therefore, several family-based programs that cooperates with schools should be implementing to ensure the adolescents use their time beneficially as in the United States (Garces et al., 2002), Great Britain (Melhuish et al., 2008), and Cuba (Hertzman et al., 2009). All three countries emphasis on the quality of care and education of adolescents from the early stages of childcare as well as transforming adolescents toward positive behaviors.

\section{References}

Achenbach, T. M., \& Edelbrock, C. S. (1983). Taxonomic issues in child psychopathology. In Handbook of child psychopathology (pp. 65-93). Springer, Boston, MA.

Allen-Meares, P. (2007). Cultural competence: An ethical requirement. Journal of Ethnic \& Cultural Diversity in Social Work, 16(3-4), 83-92.

Amna, M. N., Asnarulkhadi A. S., Rozumah, B., Abdullah A. H. M., Rumaya, J., Mansor, A. T., \& Jo-Pei, T. (2003). Sistem Sekolah dan Sosialisasi Pelajar. Penerbit Universiti Putra Malaysia

Arce, R., Seijo, D., Fariña, F., \& Mohamed-Mohand, L. (2010). Comportamiento antisocial en menores: Riesgo social y trayectoria natural de desarrollo. Revistamexicana de

Asiah, A. R. (2001). IIUM Press. International Islamic.

Banks, J. A. (1993). Chapter 1: Multicultural education: Historical development, dimensions, and practice. Review of research in education, 19(1), 3-49.

Bernberg, J. G., Krohn, M. D., \& Rivera, C. J. (2006). Official labeling, criminal embeddedness, and subsequent delinquency: A longitudinal test of labeling theory. Journal of Research in Crime and Delinquency, 43(1), 67-88.

Bokhorst, C. L., Sumter, S. R., \& Westenberg, P. M. (2010). Social support from parents, friends, classmates, and teachers in children and adolescents aged 9 to 18 years: Who is perceived as most supportive? Social development, 19(2), 417-426.

Brookover, W. B., \& Lezotte, L. W. (1979). Changes in School Characteristics Coincident with Changes in Student Achievement. Occasional Paper No. 17.

Chandra, A., Martino, S. C., Collins, R. L., Elliott, M. N., Berry, S. H., Kanouse, D. E., \& Miu, A. (2008). Does watching sex on television predict teen pregnancy? Findings from a national longitudinal survey of youth. Pediatrics, 122(5), 1047-1054.

Combs, A. W. (1981). Humanistic education: Too tender for a tough world? The Phi Delta Kappan, 62(6), 446-449.

Deal, T. E., \& Peterson, K. D. (1999). Shaping school culture: The heart of leadership Adolescence, 34(136), 802.

Eggen, A. B. (2004). Alfa and omega in student assessment: Exploring identities of secondary school science teachers.

Franken, R. (1994). Human motivation (3rd ed.). Pacific Grove, CA: Brooks/Cole Publishing Co.

Garces, E., Thomas, D., \& Currie, J. (2002). Longer-term effects of Head Start. American economic review, 92(4), 999-1012.

Gilman, R., \& Huebner, E. S. (2006). Characteristics of adolescents who report very high life satisfaction. Journal of youth and adolescence, 35(3), 293-301.

Gresham, F. M., Lane, K. L., MacMillan, D. L., Bocian, K. M., \& Ward, S. L. (2000). Effects of positive and negative illusory biases: Comparisons across social and academic selfconcept domains. Journal of school psychology, 38(2), 151-175.

Heng-ai lin. (2009). An Investigation into the Status Quo of Normal University Students' Achievement Goals. Health Medicine Research and Practice, 05. 
Hertzman, C., \& Williams, R. (2009). Making early childhood count. Cmaj, 180(1), 68-71.

Houck, C., Javdani, S., Sadeh, N., White, H. I., Emerson, E., Brown, L. K., \&Donenberg, G. R. (2010). Contextualizing pubertal development: The combination of sexual partners' age and girls'pubertal development confers risk for externalizing but not internalizing symptoms among girls in therapeutic day schools. Journal of adolescence, 71, 84-90.

Ismail, M. R. B. (2008).

HubunganRekabentukLandskapSekolahDenganPencapaianPrestasiAkademikPelajarSek olahMenengah di Besut, Terengganu.

Johansson, U. (2004). Long-term outcome after brain injury with a focus on return to work, life satisfaction and participation (Doctoral dissertation, Arbetsterapi, UmeaUniversitet).

Joussemet, M., Landry, R., \& Koestner, R. (2008). A self-determination theory perspective on parenting. Canadian Psychology/Psychology Canadienne, 49(3), 194.

Kaplan, D. L., Jones, E. J., Olson, E. C., \& Yunzal-Butler, C. B. (2013). Early age of first sex and health risk in an urban adolescent population. Journal of School Health, 83(5), 350-356.

Kosnin, M., Azlina, H., Mustapha, S. S. (2010). Kaitan Antara FaktorFaktorKekeluargaanDenganTingkahLakuDelikuensiPelajar.

Krejcie, R. V., \& Morgan, D. W. (1970). Determining sample size for research activities. Educational and psychological measurement, 30(3), 607-610.

Levy, J. S. (1997). Prospect theory, rational choice, and international relations. International studies quarterly, 41(1), 87-112.

Lillemyr, O. F. (2004). Social learning through social motivation. Contemporary perspectives on research in socialization and social development, 99-132.

Bryant, L. A., \& Eccles, J. S. (2007). Psychosocial, motivational, and contextual profiles of youth reporting different patterns of substance use during adolescence. Journal of Research on Adolescence, 17(1), 51-88.

Madruga, C. S., Laranjeira, R., Caetano, R., Pinsky, I., Zaleski, M., \&Ferri, C. P. (2012). Use of licit and illicit substances among adolescents in Brazil-A national survey. Addictive Behaviors, 37(10), 1171-1175.

Marsh, H. W., Parada, R. H., \& Ayotte, V. (2004). A multidimensional perspective of relations between self-concept (Self Description Questionnaire II) and adolescent mental health (Youth Self-Report). Psychological Assessment, 16(1), 27.

Matsunaga, M. (2011). Cognitive behavioral therapy for depression changes medial prefrontal and ventral anterior cingulate cortex activity associated with self-referential processing. Social cognitive and affective neuroscience, 9(4), 487-493.

Melhuish, E., Belsky, J., Leyland, A. H., Barnes, J., \& National Evaluation of Sure Start ResearchTeam. (2008). Effects of fully-established Sure Start Local Programmed on 3year-old children and their families living in England: a quasi-experimental observational study. The Lancet, 372(9650), 1641-1647.

Ming, C. C., \& Kong, J. T. (2003). A study on learning strategy and the effect of group counseling for learning of senior high students.

Mota, C. P., \& Matos, P. M. (2013). Peer attachment, coping, and self-esteem in institutionalized adolescents: The mediating role of social skills. European journal of psychology of education, 28(1), 87-100.

Muhammadi, N. (2015). Hubungankepimpinanpengetua Madrasah, prestasi guru dan budayabelajardalammeningkatkankualiti di Madrasah Tsanawiyah negeri Jakarta Selatan (Doctoral dissertation, Universiti Pendidikan Sultan Idris). 
Ngai, N. P., \& Cheung, C. K. (2005). Predictors of the likelihood of delinquency: A study of marginal youth in Hong Kong, China. Youth \& Society, 36(4), 445-470.

Noraziah, A. (2003). High service reliability for cluster server systems. In 2003 Proceedings IEEE International Conference on Cluster Computing (pp. 281-281). IEEE Computer Society.

Obiunu, J. J. (2015). Relationship between Parents and Peer Influences on Qualities of Adolescent Friendship. Journal of Education and Practice, 6(8), 128-133.

Orth, U., Robins, R. W., \& Widaman, K. F. (2012). Life-span development of self-esteem and its effects on important life outcomes. Journal of personality and social psychology, 102(6), 1271.

Orth, U., Robins, R. W., Trzesniewski, K. H., Maes, J., \& Schmitt, M. (2009). Low self-esteem is a risk factor for depressive symptoms from young adulthood to old age. Journal of abnormal psychology, 118(3), 472.

Patterson, G. R., DeBaryshe, B. D., \& Ramsey, E. (1999). A developmental perspective on antisocialbehavior (Vol. 44, No. 2, p. 329). American Psychological Association. psicología, 27(2), 127-142.

Rill, L., Baiocchi, E., Hopper, M., Denker, K., \& Olson, L. N. (2009). Exploration of the relationship between self-esteem, commitment, and verbal aggressiveness in romantic dating relationships. Communication Reports, 22(2), 102-113.

Rogers, A. (1981). Model migration schedules

Rudasill, K. M., Snyder, K. E., Levinson, H., \& Adelson, J. L. (2017). Systems view of school climate: A theoretical framework for research. Educational psychology review, 30(1), 35-60.

Seaton, M., Parker, P., Marsh, H. W., Craven, R. G., \& Yeung, A. S. (2004). The reciprocal relations between self-concept, motivation and achievement: Juxtaposing academic self-concept and achievement goal orientations for mathematics success. Educational psychology, 34(1), 49-72.

Shochet, I. M., Dadds, M. R., Ham, D., \& Montague, R. (2006). School connectedness is an underemphasized parameter in adolescent mental health: Results of a community prediction study. Journal of Clinical Child \& Adolescent Psychology, 35(2), 170-179.

Stolp, S. (1995). Transforming School Culture: Stories, Symbols, Values \& the Leader's Role. ERIC Clearinghouse on Educational Management, 5207 University of Oregon, 1787 Agate Street, Eugene, OR 97403-5207.

Tam, C. L., \& Lim, S. G. (2009). Perceived social support, coping capability and gender differences among young adults. Sunway Academic Journal, 6, 75-88.

Thomaes, K., Dorrepaal, E., Draijer, N., de Ruiter, M. B., van Balkom, A. J., Smit, J. H., \&Veltman, D. J. (2010). Reduced anterior cingulate and orbitofrontal volumes in child abuse-related complex PTSD. The Journal of clinical psychiatry, 71(12), 0-0.

Trzesniewski, K. H., Donnellan, M. B., Moffitt, T. E., Robins, R. W., Poulton, R., \& Caspi, A. (2006). Low self-esteem during adolescence predicts poor health, criminal behavior, and limited economic prospects during adulthood. Developmental psychology, 42(2), 381.

UNICEF. (2018). Adolescent health the missing population in universal health coverage.

Virtanen, K. A., Lidell, M. E., Orava, J., Heglind, M., Westergren, R., Niemi, T., \& Nuutila, P. (2009). Functional brown adipose tissue in healthy adults. New England Journal of Medicine, 360(15), 1518-1525. 
World Health Organization. (2017). WHO report on the global tobacco epidemic, 2017: monitoring tobacco use and prevention policies? World Health Organization.

Zainudin, S., \& Norazmah, M. R. (2011). Faktor-Faktor Yang Mempengaruhi Remaja Terlibat Dalam Sosial Di Sekolah Tunas Bakti, Sungai Lereh, Melaka. JurnalPendidikan Psikologi Pendidikan \& Kaunseling 1(115) 2231-35X

Zulkifli, S. N., \& Low, W. Y. (2000). Sexual practices in Malaysia: determinants of sexual intercourse among unmarried youths. Journal of adolescent health, 27(4), 276-280. 